\title{
Combination therapy: A feasibility strategy for CAR-T cell therapy in the treatment of solid tumors (Review)
}

\author{
JINJING XU* ${ }^{*}$ YALI WANG* ${ }^{*}$ JING SHI, JUAN LIU, QINGGUO LI and LONGZHOU CHEN \\ Galactophore Department, Jiangsu Huai'an Maternity and Children Hospital, Huai'an, Jiangsu 223001, P.R. China
}

Received September 29, 2017; Accepted March 7, 2018

DOI: $10.3892 / \mathrm{ol} .2018 .8946$

\begin{abstract}
Chimeric antigen receptor (CAR) T-cell therapies have been demonstrated to have durable and potentially curative therapeutic efficacies in patients with hematological malignancies. Currently, multiple clinical trials in CAR-T cell therapy have been evaluated for the treatment of patients with solid malignancies, but have had less marked therapeutic effects when the agents are used as monotherapies. When summarizing relevant studies, the present study found that combination therapy strategies for solid tumors based on CAR-T cell therapies might be more effective. This review will focus on various aspects of treating solid tumors with CAR-T cell therapy: i) The therapeutic efficacy of CAR-T cell monotherapy, ii) the feasibility of the CAR-T cell therapy in conjunction with chemotherapy, iii) the feasibility of CAR-T cell therapy with radiotherapy, iv) the feasibility of CAR-T cell therapy with chemoradiotherapy, and v) the feasibility of the combination of CAR-T cell therapy with other strategies.
\end{abstract}

\section{Contents}

1. Introduction

2. Therapeutic efficacy of CAR-T cell monotherapy in the treatment of solid tumors

3. Feasibility of using CAR-T cell therapy with chemotherapy for treatment of solid tumors

4. Feasibility of using CAR-T cells with radiotherapy for treatment of solid tumors

Correspondence to: Dr Longzhou Chen, Galactophore Department, Jiangsu Huai'an Maternity and Children Hospital, 104 People South Road, Huai'an, Jiangsu 223001, P.R. China E-mail: chenlongzhou691001@163.com

*Contributed equally

Key words: Chimeric antigen receptor-T cell therapy, solid tumor, combination therapy, chemotherapy, radiotherapy, programmed cell death protein 1/programmed cell death 1 ligand 1 blockade, oncolytic virus
5. Feasibility of employing CAR-T cell therapy with chemoradiotherapy for treatment of solid tumors

6. Feasibility of CAR-T cell therapy with other immunotherapy strategies for treatment of solid tumors

7. Conclusion and discussion

\section{Introduction}

Chimeric antigen receptor (CAR) T-cell therapy has emerged as a potentially curative therapy in the treatment of a broad range of malignancies (1). CARs generally consist of an extracellular single-chain variable fragment ( $\mathrm{scFv}$ ) of an antibody for target recognition, a transmembrane domain fused with co-stimulation signaling domains, such as CD28 or 4-1BB, and a CD3 $\zeta$ signaling domain to provide T-cell activation signals (2-4). Additionally, antigen recognition by CAR-T cells occurs in a major histocompatibility complex (MHC)-independent manner, which helps to overcome tumor immune evasion by the down-regulation of MHC molecules on the cell surface $(5,6)$.

To date, even though CAR-T cells have demonstrated dramatic efficacy in patients with hematological malignancies, particularly in treating B-cell hematologic malignancies with CD19-specific CAR T-cells (7,8), the clinical application of CAR-T cells in the treatment of solid tumors has not yet been successful, which raises questions about the feasibility of CAR-T cell therapy for the treatment of solid tumors (9-11). Nevertheless, the present authors wanted to determine whether CAR-T cell therapy has a curative effect on solid tumors and which is the best way to correctly establish the role of CAR-T cell therapy in the treatment of solid tumors. In the present review, the feasibility of combining CAR-T cell therapy with other treatments, such as chemotherapy, radiotherapy, chemoradiotherapy and other immunotherapy strategies is illustrated (Fig. 1).

\section{Therapeutic efficacy of CAR-T cell monotherapy in the treatment of solid tumors}

Most clinical studies have shown that CAR-T cell monotherapy had insufficient efficacy to treat solid tumors. For example, in a clinical study from Lamers et al (12) on renal carcinoma patients with first-generation CAIX-specific CAR-T cells, they observed low clinical response rates $(9,12)$. Similar effects have been observed in neuroblastoma patients treated with first-generation CD171-specific CAR-T cells (13), patients with ovarian cancer 
treated with epidermal growth factor receptor (EGFR)-specific CAR-T cells (14) or $\alpha$-folate receptor (FR)-specific CAR-T cells (15), and colon cancer patients treated with third-generation Her-2-specific CAR-T cells (16). A study from Louis et al (17) reported that of neuroblastoma patients who received GD2-specific CAR-T cells, some did not respond at all, and some exhibited disease progression during or following treatment.

Although clinical datahave revealed that the efficacy of CAR-T cell monotherapy in the treatment of solid tumors is limited, the present authors still consider CAR-T cell therapy as a potential therapy to treat solid tumors. The full potential of CAR-T cell therapy is not understood due to the main reasons for the failure of CAR-T cell monotherapy to treat solid tumors, which are as follows. Firstly, current patients in CAR-T cell therapy clinical trials are patients who have received many other treatments that have not worked. The patients' physical conditions are already poor. Secondly, it is not possible for heavy-burden solid tumors to be eradicated by CAR-T cell monotherapy. Therefore, greater value and better results might be seen with CAR-T cell therapy in treating solid tumors if patients with early-stage-cancer were selected and CAR-T cell therapy was combined with other therapies, such as chemotherapy, radiotherapy, surgery and other immunotherapy strategies.

\section{Feasibility of using CAR-T cell therapy with chemotherapy for treatment of solid tumors}

Preclinical and clinical studies have demonstrated that CAR-T cell therapy and chemotherapy alone are not sufficient to eradicate large solid tumors or metastasis, resulting in recurrence or refractory disease $(9,18)$. A large amount of data has suggested that the combination of chemotherapy with CAR-T cell therapy should be attempted, and novel combination strategies should show potential synergistic effects in practice in the future $(19,20)$.

Chemotherapy is able to improve the efficacy of CAR-T cell therapy. Recent studies have indicated that a number of chemotherapeutic agents, including cyclophosphamide, doxorubicin, oxaliplatin, fluorouracil and gemcitabine, are not only able to reduce tumor burden but also have considerable immunomodulatory effects (21-23). It has been reported that the combination of immunotherapy with chemotherapy may achieve a more prominent curative effect than monotherapy (20). In the following section, the pathways by which chemotherapeutic agents induce the immune response, which should promote the curative effect of T-cells, are reviewed and then the feasibility of the combination of CAR-T cells with chemotherapy is analyzed (Fig. 2).

Chemotherapeutic agents are able to sensitize tumor cells to immunotherapy. Studies have indicated that mannose-6-phosphate receptors on tumor cell surfaces are upregulated following treatment with certain chemotherapeutic agents, which makes it easier for granzyme B released by cytotoxic T lymphocytes (CTL) to permeate tumor cells, sensitizing tumor cells to immunotherapy in an autophagy-dependent manner (24-26). Apart from this, one preclinical case of ErbB-retargeted T-cells combined with carboplatin demonstrated that treatment with low doses of the chemotherapeutic agent carboplatin was able to sensitize tumor cells to specific-ErbB

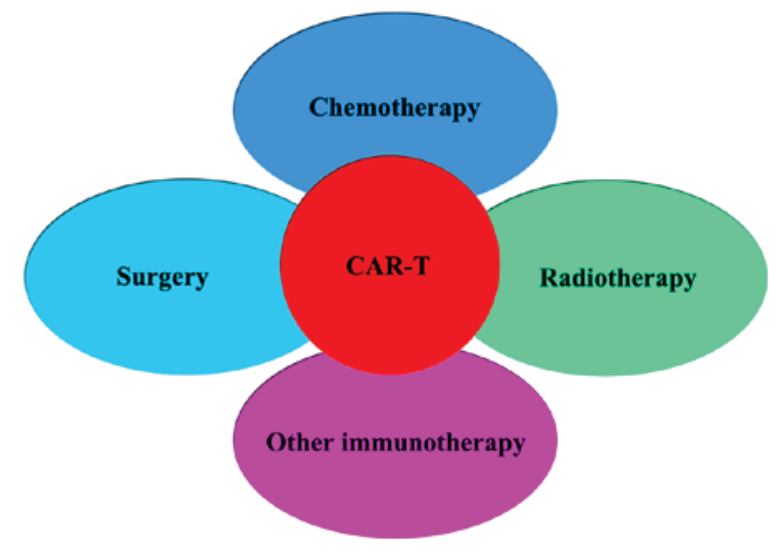

Figure 1. Combination strategies based on CAR-T. The effects of chemotherapy, surgery, radiotherapy and other strategies are expected to be complementary or synergistic, and may remarkably improve the efficacy of antitumor therapy in the future. CAR-T, chimeric antigen receptor T-cell.

CAR T-cell-mediated cytotoxicity and enhance the efficacy of the antitumor immunotherapy $(27,28)$. The mechanisms of increasing sensitivity to immunotherapy following treatment with certain chemotherapeutic agents are not fully understood, but in other studies, the enhanced therapeutic efficacy was also observed following combination therapy (29).

Chemotherapeutic agents are able to improve tumor antigen recognition and presentation. Research has indicated that certain chemotherapeutic agents, such as taxanes (docetaxel and paclitaxel) and vinca alkaloids (vinorelbine and vinblastine), were able to facilitate tumor cell recognition by increasing exposure to calreticulin and killing tumor cells, thereby releasing large quantities of tumor antigens (30). In addition, studies have indicated that a number of chemotherapeutic agents were able to improve tumor antigen presentation. The main pathways are as follows. Firstly, autophagy induced by some chemotherapeutic agents stimulates tumor cells to release ATP, which increase the recruitment of dendritic cells (DCs) and T lymphocytes to infiltrate the tumor bed for tumor antigen presentation (21,31-33). Secondly, it has been reported that the dying tumor cells induced by chemotherapeutic agents release damage-associated molecular patterns (DAMPs), such as high-mobility group box 1 (HMGB1), which could be recognized by Toll-like receptor 4 to promote DC maturation and activation, enhancing the antitumor T-cell response (34-37). Thirdly, chemotherapeutic agents induce tumor cells or stromal cells to generate endogenous type I interferons (IFNs) and increases the exogenous type I IFNs, which can activate DC and induce T cell cross-priming, leading to tumor control $(20,22,38)$.

Certain chemotherapeutic agents are able to inhibit suppressive immune cells. It has been confirmed that certain chemotherapeutic agents (doxorubicin, fluorouracil, gemcitabine, cyclophosphamide and docetaxel) are able to selectively inhibit immunosuppressive cells (regulatory $\mathrm{T}$ cells and myeloid-derived suppressor cells) to enhance the efficacy of antitumor immunotherapy (39). Studies have revealed that certain immunosuppressive cells are more sensitive than T-cells to some chemotherapeutic agents, and 


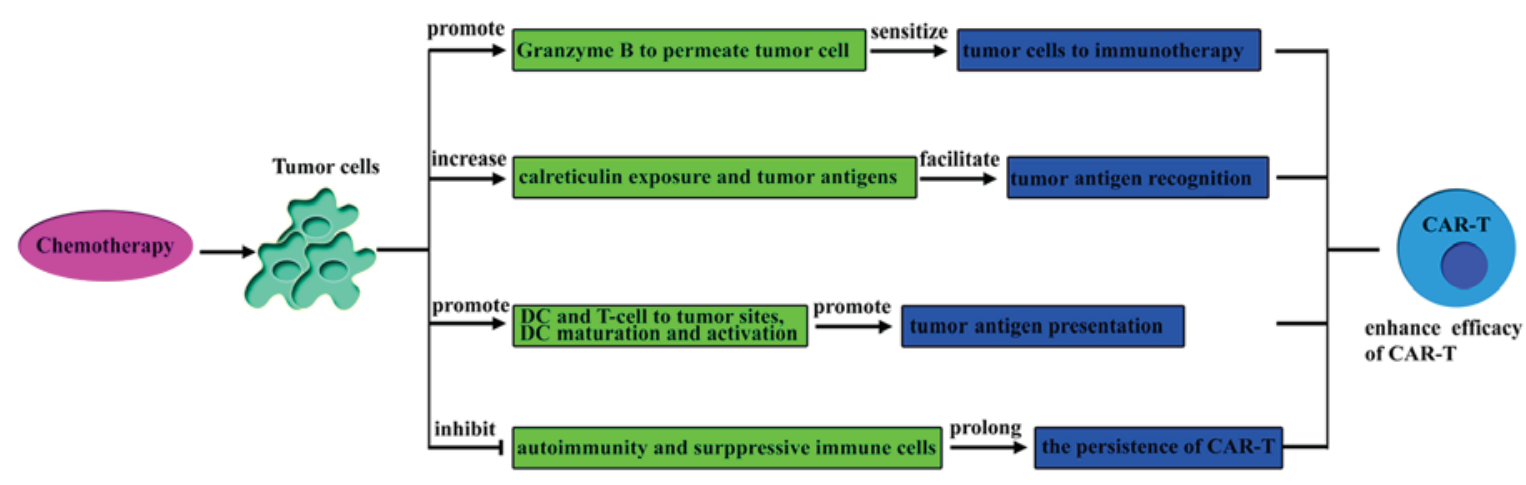

Figure 2. Mechanisms for how chemotherapy improves the efficacy of CAR-T. CAR-T, chimeric antigen receptor T-cell; DC, dendritic cells.

low-dose chemotherapeutics were not detrimental to adoptive $\mathrm{T}$ cells (40-42).

Chemotherapy is able to inhibit autoimmunity and prolong the persistence of CAR-T cells in vivo. Accumulating preclinical and clinical studies have demonstrated that after repeated cycles of intensive treatment with chemotherapy, autoimmunity is inhibited, which is a lethal side effect (43-45). Nevertheless, inhibited autoimmunity may increase the efficacy of adoptive T-cell transfer in cancer patients (19). Early CAR-T cell therapy trials without conditioning chemotherapy demonstrated a short persistence of CAR-T cells and poor results in the treatment of solid tumors $(15,16,46)$. Recent studies have confirmed that conditioning chemotherapy is able to inhibit autoimmunity and remove suppressive cells to prolong the persistence of CAR-T cells in vivo, thereby boosting their curative effects $(47,48)$. In addition, the studies demonstrated that conditioning chemotherapy is able to counteract the potential immunogenicity of CAR-T cells and provide homeostatic cytokines to CAR-T cells to reduce the toxicity $(47,48)$.

T-cells can amplify the efficacy of chemotherapy. It has been demonstrated that the innate and adaptive immune systems are able to contribute considerably to the efficacy of chemotherapy in the treatment of cancer (49). A recent study by Wang et al (50) in Cell indicated that effector T-cells abrogate stroma-mediated chemoresistance in ovarian cancer. Wang et al (50) demonstrated that fibroblasts release glutathione and cysteine, which contribute to chemoresistance. T-cells were able to change the metabolism of glutathione and cysteine by releasing IFN- $\gamma$ in fibroblasts via the Janus kinase 1/signal transducer and activator of transcription 1 signaling pathway, thereby abolishing chemoresistance. In addition, accumulating preclinical and clinical studies have demonstrated that following repeated cycles of intensive treatment with chemotherapy, autoimmunity was inhibited, which is a lethal side effect (43-45). Therefore, it is urgent to evaluate the application of adoptive $\mathrm{T}$ cells to restore the human immune system and to maintain the stability of the internal environment. Therefore, as one example of adoptive T-cells, CAR-T cells can amplify the efficacy of chemotherapy.

In conclusion, the combination of chemotherapy with CAR-T cell therapy may have synergistic effects, and further research on novel combination strategies may provide an opportunity to use the full potential of CAR-T cells in the treatment of solid tumors.

\section{Feasibility of using CAR-T cells with radiotherapy for treatment of solid tumors}

Currently, accumulating evidence supports the concept that antitumor effects can be additive or even synergistic when radiotherapy is combined with immunotherapy $(51,52)$. There are a number of rationales for employing CAR-T cells in conjunction with radiotherapy when treating solid tumors.

Radiotherapy is able to improve the efficacy of CAR-T cells. It has been increasingly observed that apart from eradication of tumor cells, radiotherapy can also stimulate tumor-specific immunity to enhance tumor control both locally and distantly $(34,53)$. This observation may serve as a rationale to demonstrate that radiotherapy can improve the efficacy of CAR-T cells in the treatment of solid tumors (Fig. 3).

Radiotherapy is able to sensitize tumor cells to tumor-specific cytotoxic lymphocytes. Reports have demonstrated that the local radiation of tumors can enhance the expression of $\mathrm{MHC}$ class I molecules and tumor-specific antigens on irradiated tumor cells, rendering them more susceptible to tumor-specific cytotoxic lymphocytes, which boosts the efficacy of adoptive CTL immunotherapy $(51,53,54)$.

Radiotherapy is able to create a tumor microenvironment conducive to CAR-T cell trafficking and infiltration. It has been generally accepted that the trafficking and infiltration of effector $\mathrm{T}$ cells into solid tumors is required for successful antitumor immune responses (55). Studies have indicated that following radiation, the release of IFN- $\gamma$ and DAMPs increases, which attracts immune effector cells to the tumor microenvironment, boosting the trafficking capability of immune effector cells and creating a tumor microenvironment conducive to T-cell infiltration (56-58). Consistent with this finding, it has been proposed that local radiation may induce the expression of certain chemokines, including C-X-C motif chemokine ligand (CXCL)9, 10 and 16 , to promote the recruitment of T-cells into the tumor microenvironment and to increase the infiltration of immune effector cells $(56,59,60)$. Additionally, local radiation also contributed to a greater infiltration of lymphocytes into the tumor as it reverses the non-adhesive phenotype of the tumor endothelium (57). 


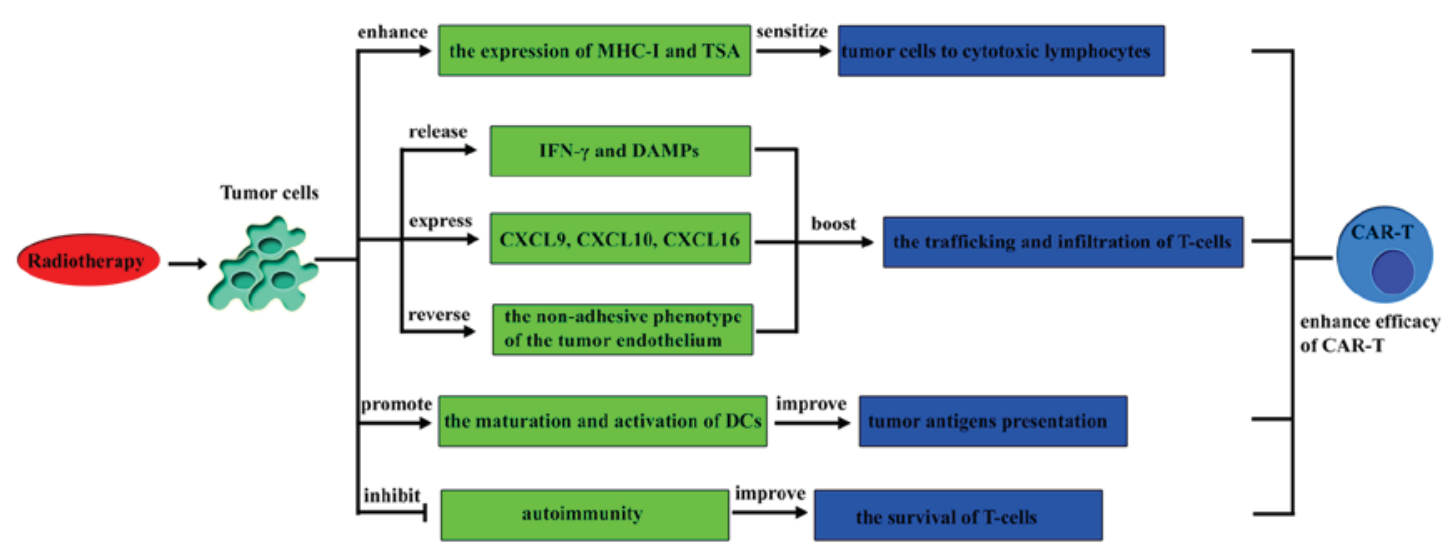

Figure 3. Mechanisms for how radiotherapy improves the efficacy of CAR-T. DC, dendritic cells; TSA, tumor specific antigen; CAR-T, chimeric antigen receptor T-cell; CXCL, chemokine C-X-C motif ligand; DAMP, damage-associated molecular pattern, IFN, interferon; MHC-1, major histocompatibility complex 1.

Radiotherapy is able to improve tumor antigen presentation. It has been increasingly observed that radiotherapy is able to increase tumor antigen presentation (61). Radiotherapy is able to induce apoptosis and necrosis of tumor cells, causing them to release danger signals, including HMGB1 (34). Subsequently, the danger signals and tumor antigens may potentially trigger type I IFN in the tumor microenvironment, serving as a link between innate responses and adaptive immunity $(62,63)$. This interaction between the innate responses and adaptive immunity has critical roles in promoting the maturation and activation of DCs to improve tumor antigen presentation (64-66).

Rationale behind T-cells amplifying the efficacy of radiotherapy. It has been proposed that radiotherapy is often associated with local or distal tumor relapse, and the response to radiotherapy is partially dependent on the tumor microenvironment and the local immune system, particularly the T-cells (56). Studies have indicated that $\mathrm{CD}^{+}{ }^{+} \mathrm{T}$-cells and their cytokines have an essential role in maintaining control over irradiated solid tumors to reduce recurrence and metastasis $(55,67,68)$.

Furthermore, following local radiation therapy, CTL may not only be attracted to irradiated tissue to induce local responses but may also be able to inhibit distant tumors, which is a phenomenon known as the abscopal effect (69). This changes radiotherapy from a regional antitumor therapeutic modality to a therapy that can target distant metastasis. Furthermore, CAR-T cell therapy can enhance the functions of T-cells, so the antitumor effects should be further amplified by combining radiotherapy with CAR-T cell therapy (70). Clinical trials evaluating the feasibility of this approach are starting. For instance, a phase 1 study at Duke University (ClinicalTrials.gov identifier, NCT02664363) aims to evaluate the safety and efficacy of EGFRvIII CAR-T cells in combination with the standard of care radiation therapy. Based on the rationale above, the present authors hypothesize that a combination of CAR-T cell therapy and radiotherapy for treatment of solid tumors should be additive or synergistic and may add a new perspective to existing treatments.

\section{Feasibility of employing CAR-T cell therapy with chemoradiotherapy for treatment of solid tumors}

Chemoradiation therapy (CRT) has an important role in the treatment of solid tumors. However, Yovino and Grossman (71)

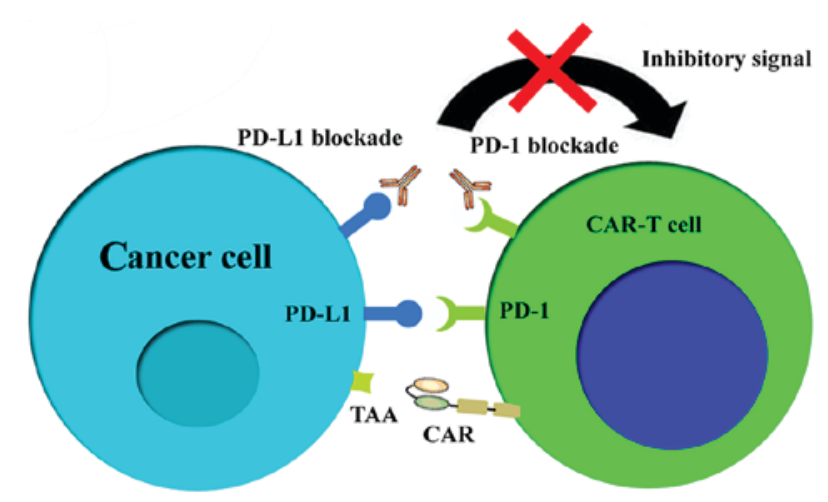

Figure 4. Mechanism of action of CAR-T with PD-1/PD-L1 blockade. PD-1, programmed death-1; PD-L1, programmed death-1 ligand; TAA, tumor associated antigen; CAR, chimeric antigen receptor.

indicated that CRT is able to result in treatment-associated toxicities, including effects on host immunity, such as lymphopenia. In addition, a number of studies have demonstrated T cells would be exhausted when solid tumors are treated with CRT, which result in elimination of a subset of immune cells $(72,73)$. This might reduce the antitumor functions of CRT and promote tumor metastasis and recurrence $(74,75)$. In particular, $\mathrm{T}$ cells are critical in mediating cellular immunity against neoplastic cells (76-78). Therefore, it might be feasible to infuse adoptive $\mathrm{T}$ cells in order to improve the antitumor effect of chemoradiotherapy and to prevent metastasis and recurrence. Unfortunately, given that the development of CAR-T cell therapy in solid tumors is at early stages, studies that combine chemoradiotherapy and CAR-T cell therapy have not yet been completed.

Several studies have demonstrated that the immune system has a critical role in promoting antitumor defense, and a low absolute lymphocyte count during therapy is associated with poorer clinical outcomes (79-81). Although the role of CAR-T cell therapy in combination with CRT in solid tumors is unknown, the approach remains promising. Buka et al (82) indicated that combining CRT with CAR-T cell therapy may be particularly efficacious due to the increased density of T cells following CRT that is associated with a median survival rate 2.5 times longer than the CRT monotherapy. Meanwhile, Zitvogel et al (83) and Aranda et al (84) indicated that CRT 
might promote the antitumor efficacy of CAR-T cell therapy as a number of CRT regimens can stimulate $\mathrm{T}$ cells, which accounts for the clinical response induced by these therapies.

\section{Feasibility of CAR-T cell therapy with other immunotherapy strategies for treatment of solid tumors}

Accumulating evidence has demonstrated that the immunosuppressive microenvironment induced by solid tumors can limit the efficacy of CAR-T cell therapy (85). Tumors can evade immune surveillance by stimulating immune inhibitory receptors on $\mathrm{T}$ cells, including $\mathrm{T}$-cell membrane protein-3, cytotoxic $\mathrm{T}$ lymphocyte-associated antigen (CTLA)-4 and programmed death (PD)-1 (86-88). The majority of solid tumors upregulate immune checkpoint ligands, leading to the inhibition of CAR-T cell therapies by stimulating immune inhibitory receptors $(89,90)$. Antibodies that block CTLA-4 (ipilimumab and tremelimumab), PD-1 (nivolumab, pembrolizumab and pidilizumab) and PD-L1 (MDX-1105 and MPDL3280A) have recently been approved by the US Food and Drug Administration for use in certain solid tumors (91). Considering this issue, whether greater curative effects are obtained after combining CAR-T cell therapy with immune checkpoint inhibitors were examined.

Preclinical studies by John et al (92), Liu et al (93) and Cogdill et al (94) have demonstrated that CAR-T cell therapy and PD-1 blockade was highly synergistic, leading to long-term survival without causing any signs of pathology in vivo. Similar effects have been observed by Moon et al (95), Burga et al (96), Suarez et al (97) and Rosewall Shaw et al (98). The proposed mechanism of action of CAR-T with PD-1/PD-L1 blockade is illustrated in Fig. 4. To overcome the immunosuppressive microenvironment, Li et al (99) engineered T cells to secret checkpoint inhibitors that target PD-1 (CAR.aPD1-T) and evaluated its efficacy in a human lung carcinoma xenograft mouse model. Li et al (99) demonstrated that the secretion of anti-PD-1 enhanced the antitumor activity of CAR-T cells and prolonged overall survival. Furthermore, Serganova et al (100) showed that employing prostate-specific membrane antigen-specific CAR-T cell therapy alone to treat prostate cancer was unsuccessful, whereas the combination of CAR-T cell therapy and a PD-1 blockade provided a partial, short-duration and sub-optimal response (100).

In clinical trials, the combination of CAR-T cell therapy and PD-1 blockade has been further evaluated. Gargett et al (101) revealed that combining a $\mathrm{PD}-1$ checkpoint inhibitor with CAR-T cell therapy may be useful in augmenting the efficacy and persistence of CAR-T cells in patients.

A primary reason for the limited application of CAR-T cell therapy in solid tumors is that penetration by immune cells is difficult (102). It has been confirmed that CAR-T cell therapy could be directed to the tumor tissues through the coexpression of chemokine receptors (CXCR2 or CCR4) or through combination with chemokines $(103,104)$. Xia et al (105) suggested that combining an oncolytic virus with CAR-T cell therapy may be particularly efficacious in stimulator of interferon genes protein-inactivated and type I IFN-disrupted tumors. By contrast, Ajina and Maher (106), Kim (107) and Scott et al (108) indicated that oncolytic virus infection might augment entry and mobilization of CAR-T cells, and mitigate or reverse local immunosuppression and enhance the function and persistence of CAR-T cell effectors.

With regards to efficient targeting of CAR T-cells, Nishio et al (109) combined GD2-specific CAR-T cell therapy with an oncolytic virus expressing RANTES and IL-15 in the treatment of neuroblastoma-bearing mice. They demonstrated that RANTES and IL-15 attracted CAR-T cells and promoted their local survival. In addition, the survival of CAR-T cells in solid tumors was improved by combining CAR-T cells with the armed oncolytic virus (110).

\section{Conclusion and discussion}

CAR-T cell therapy has an important role in controlling and eradicating malignant cells, particularly in the treatment of hematologic malignancies. However, expanding the use of CAR-T cell therapy to solid cancers raises challenges (111). When summarizing the relevant studies, it was found that combination therapy based on CAR-T cell therapy for solid tumors is feasible and may allow the full potential of CAR-T cell therapy to be realized.

However, it is critical to determine which patients require combination strategies, what combinations are best in any given patient and how best to combine such agents. First, some patients that benefit from monotherapy do not require combination therapy and should not be administered combination therapy in order to avoid toxicities associated with combination therapy. Therefore, it is urgent for us to develop biomarkers to identify such patients to preselect them for monotherapy (112). Secondly, for patients who require combination therapy, the identification of such predictive biomarkers is also important to determine the optimal combination of therapies. Thirdly, to employ novel combination therapy strategies (a mixture of CAR-T cell therapy and chemotherapy, radiotherapy, chemoradiotherapy or other regimens) in preclinical and clinical settings, the timing, dosage, frequency, fractionation, and treatment sequences need to be defined.

In conclusion, novel combination strategies for the treatment of solid tumors deserve further study to minimize toxicity while maximizing antitumor efficacy.

\section{Acknowledgements}

Not applicable.

\section{Funding}

No funding was received.

\section{Availability of data and materials}

The datasets used and analyzed during the current study are available from the corresponding author on reasonable request.

\section{Authors' contributions}

LZC contributed the central idea and analysed most of the data. JJX analyzed and interpreted the data regarding the combination of CAR-T with chemotherapy in the treatment of solid tumors. YLW analyzed and interpreted the data 
regarding CAR-T monotherapy in solid tumors treatment. JS analyzed and interpreted the data regarding the combination of CAR-T with radiotherapy in the treatment of solid tumors. JL and QGL analyzed and interpreted the data regarding the combination of CAR-T with other immunotherapy strategies in the treatment of solid tumors. JJX and YLW wrote the initial draft of the paper. The remaining authors finalized this paper. All authors read and approved the final manuscript.

\section{Ethics approval and consent to participate}

Not applicable.

\section{Consent for publication}

Not applicable.

\section{Competing interests}

The authors declare that they have no competing interest.

\section{References}

1. Yang JC and Rosenberg SA: Adoptive T-cell therapy for cancer. Adv Immunol 130: 279-294, 2016.

2. Maus MV and June $\mathrm{CH}$ : Making better chimeric antigen receptors for adoptive T-cell therapy. Clin Cancer Res 22: 1875-1884, 2016.

3. Whilding LM and Maher J: CAR T-cell immunotherapy: The path from the by-road to the freeway? Mol Oncol 9: 1994-2018, 2015.

4. Haji-Fatahaliha M, Hosseini M, Akbarian A, Sadreddini S, Jadidi-Niaragh F and Yousefi M: CAR-modified T-cell therapy for cancer: An updated review. Artif Cells Nanomed Biotechnol 44: $1339-1349,2016$

5. Sadelain M, Brentjens R and Rivière I: The basic principles of chimeric antigen receptor design. Cancer Discov 3: 388-398, 2013

6. Seliger B: Different regulation of MHC class I antigen processing components in human tumors. J Immunotoxicol 5: 361-367, 2008

7. Pan J, Yang JF, Deng BP, Zhao XJ, Zhang X, Lin YH, Wu YN, Deng ZL, Zhang YL, Liu SH, et al: High efficacy and safety of low-dose CD19-directed CAR-T cell therapy in 51 refractory or relapsed B acute lymphoblastic leukemia patients. Leukemia 31: 2587-2593, 2017.

8. Tiberghien P, Deconinck E and Adotevi O: More on anti-CD19 CAR T cells in CNS diffuse large-B-cell lymphoma. N Engl J Med 377: 2101-2102, 2017.

9. Lamers $\mathrm{CH}$, Sleijfer $\mathrm{S}$, van Steenbergen $\mathrm{S}$, van Elzakker $\mathrm{P}$ van Krimpen B, Groot C, Vulto A, den Bakker M, Oosterwijk E, Debets R and Gratama JW: Treatment of metastatic renal cell carcinoma with CAIX CAR-engineered T cells: Clinical evaluation and management of on-target toxicity. Mol Ther 21: 904-912, 2013.

10. Thistlethwaite FC, Gilham DE, Guest RD, Rothwell DG, Pillai M, Burt DJ, Byatte AJ, Kirillova N, Valle JW, Sharma SK, et al: The clinical efficacy of first-generation carcinoembryonic antigen (CEACAM5)-specific CAR T cells is limited by poor persistence and transient pre-conditioning-dependent respiratory toxicity. Cancer Immunol Immunother 66: 1425-1436, 2017.

11. Feng KC, Guo YL, Liu Y, Dai HR, Wang Y, Lv HY, Huang JH, Yang QM and Han WD: Cocktail treatment with EGFR-specific and CD133-specific chimeric antigen receptor-modified T cells in a patient with advanced cholangiocarcinoma. J Hematol Oncol 10: 4, 2017.

12. Lamers CH, Klaver Y, Gratama JW, Sleijfer S and Debets R: Treatment of metastatic renal cell carcinoma (mRCC) with CAIX CAR-engineered T-cells-a completed study overview. Biochem Soc Trans 44: 951-959, 2016.

13. Park JR, Digiusto DL, Slovak M, Wright C, Naranjo A, Wagner J, Meechoovet HB, Bautista C, Chang WC, Ostberg JR and Jensen MC: Adoptive transfer of chimeric antigen receptor re-directed cytolytic T lymphocyte clones in patients with neuroblastoma. Mol Ther 15: 825-833, 2007.
14. Sheng Q and Liu J: The therapeutic potential of targeting the EGFR family in epithelial ovarian cancer. Br J Cancer 104: 1241-1245, 2011

15. Kershaw MH, Westwood JA, Parker LL, Wang G, Eshhar Z, Mavroukakis SA, White DE, Wunderlich JR, Canevari S, Rogers-Freezer L, et al: A phase I study on adoptive immunotherapy using gene-modified T cells for ovarian cancer. Clin Cancer Res 12: 6106-6115, 2006.

16. Morgan RA, Yang JC, Kitano M, Dudley ME, Laurencot CM and Rosenberg SA: Case report of a serious adverse event following the administration of $T$ cells transduced with a chimeric antigen receptor recognizing ERBB2. Mol Ther 18: 843-851, 2010.

17. Louis CU, Savoldo B, Dotti G, Pule M, Yvon E, Myers GD, Rossig C, Russell HV, Diouf O, Liu E, et al: Antitumor activity and long-term fate of chimeric antigen receptor-positive $\mathrm{T}$ cells in patients with neuroblastoma. Blood 118: 6050-6056, 2011.

18. Anampa J, Chen A, Wright J, Patel M, Pellegrino C, Fehn K, Sparano JA and Andreopoulou E: Phase I trial of veliparib, a poly ADP ribose polymerase inhibitor, plus metronomic cyclophosphamide in metastatic HER2-negative breast cancer. Clin Breast Cancer 18: e135-e142, 2018.

19. Bracci L, Schiavoni G, Sistigu A and Belardelli F: Immune-based mechanisms of cytotoxic chemotherapy: Implications for the design of novel and rationale-based combined treatments against cancer. Cell Death Differ 21: 15-25, 2014.

20. Vierboom MP, Bos GM, Ooms M, Offringa R and Melief CJ: Cyclophosphamide enhances anti-tumor effect of wild-type p53-specific CTL. Int J Cancer 87: 253-260, 2000.

21. Michaud M, Martins I, Sukkurwala AQ, Adjemian S, Ma Y, Pellegatti P, Shen S, Kepp O, Scoazec M, Mignot G, et al: Autophagy-dependent anticancer immune responses induced by chemotherapeutic agents in mice. Science 334: 1573-1577, 2011.

22. Sistigu A, Yamazaki T, Vacchelli E, Chaba K, Enot DP, Adam J, Vitale I, Goubar A, Baracco EE, Remédios C, et al: Cancer cell-autonomous contribution of type I interferon signaling to the efficacy of chemotherapy. Nat Med 20: 1301-1309, 2014

23. Alizadeh D, Trad M, Hanke NT, Larmonier CB, Janikashvili N, Bonnotte B, Katsanis E and Larmonier N: Doxorubicin eliminates myeloid-derived suppressor cells and enhances the efficacy of adoptive T-cell transfer in breast cancer. Cancer Res 74: 104-118, 2014

24. Ramakrishnan R, Huang C, Cho HI, Lloyd M, Johnson J, Ren X, Altiok S, Sullivan D, Weber J, Celis E and Gabrilovich DI: Autophagy induced by conventional chemotherapy mediates tumor cell sensitivity to immunotherapy. Cancer Res 72: 5483-5493, 2012.

25. Motyka B, Korbutt G, Pinkoski MJ, Heibein JA, Caputo A, Hobman M, Barry M, Shostak I, Sawchuk T, Holmes CF, et al: Mannose 6-phosphate/insulin-like growth factor II receptor is a death receptor for granzyme $\mathrm{B}$ during cytotoxic $\mathrm{T}$ cell-induced apoptosis. Cell 103: 491-500, 2000.

26. Trapani JA, Sutton VR, Thia KY, Li YQ, Froelich CJ, Jans DA, Sandrin MS and Browne KA: A clathrin/dynamin- and mannose-6-phosphate receptor-independent pathway for granzyme B-induced cell death. J Cell Biol 160: 223-233, 2003.

27. Parente-Pereira AC, Whilding LM, Brewig N, van der Stegen SJ, Davies DM, Wilkie S, van Schalkwyk MC, Ghaem-Maghami S and Maher J: Synergistic chemoimmunotherapy of epithelial ovarian cancer using ErbB-retargeted T cells combined with carboplatin. J Immunol 191: 2437-2445, 2013.

28. Whilding LM and Maher J: ErbB-targeted CAR T-cell immunotherapy of cancer. Immunotherapy 7: 229-241, 2015.

29. Proietti E, Moschella F, Capone I and Belardelli F: Exploitation of the propulsive force of chemotherapy for improving the response to cancer immunotherapy. Mol Oncol 6: 1-14, 2012.

30. Senovilla L, Vitale I, Martins I, Tailler M, Pailleret C, Michaud M, Galluzzi L, Adjemian S, Kepp O, Niso-Santano M, et al: An immunosurveillance mechanism controls cancer cell ploidy. Science 337: 1678-1684, 2012.

31. Ma Y, Adjemian S, Mattarollo SR, Yamazaki T, Aymeric L, Yang H, Portela Catani JP, Hannani D, Duret H, Steegh K, et al: Anticancer chemotherapy-induced intratumoral recruitment and differentiation of antigen-presenting cells. Immunity 38: 729-741, 2013.

32. Michaud M, Xie X, Bravo-San Pedro JM, Zitvogel L, White E and Kroemer G: An autophagy-dependent anticancer immune response determines the efficacy of melanoma chemotherapy. Oncoimmunology 3: e944047, 2014. 
33. Martins I, Tesniere A, Kepp O, Michaud M, Schlemmer F, Senovilla L, Séror C, Métivier D, Perfettini JL, Zitvogel L and Kroemer G: Chemotherapy induces ATP release from tumor cells. Cell Cycle 8: 3723-3728, 2009.

34. Apetoh L, Ghiringhelli F, Tesniere A, Obeid M, Ortiz C, Criollo A, Mignot G, Maiuri MC, Ullrich E, Saulnier P, et al: Toll-like receptor 4-dependent contribution of the immune system to anticancer chemotherapy and radiotherapy. Nat Med 13: 1050-1059, 2007.

35. Obeid M, Tesniere A, Ghiringhelli F, Fimia GM, Apetoh L, Perfettini JL, Castedo M, Mignot G, Panaretakis T, Casares N, et al: Calreticulin exposure dictates the immunogenicity of cancer cell death. Nat Med 13: 54-61, 2007.

36. Garg AD, Krysko DV, Verfaillie T, Kaczmarek A, Ferreira GB, Marysael T, Rubio N, Firczuk M, Mathieu C, Roebroek AJ, et al: A novel pathway combining calreticulin exposure and ATP secretion in immunogenic cancer cell death. EMBO J 31: 1062-1079, 2012.

37. Garg AD, Galluzzi L, Apetoh L, Baert T, Birge RB, Bravo-San Pedro JM, Breckpot K, Brough D, Chaurio R, Cirone M, et al: Molecular and translational classifications of DAMPs in immunogenic cell death. Front Immunol 6: 588, 2015.

38. Proietti E, Greco G, Garrone B, Baccarini S, Mauri C, Venditti M, Carlei D and Belardelli F: Importance of cyclophosphamide-induced bystander effect on $\mathrm{T}$ cells for a successful tumor eradication in response to adoptive immunotherapy in mice. J Clin Invest 101: 429-441, 1998.

39. Lutsiak ME, Semnani RT, De Pascalis R, Kashmiri SV, Schlom J and Sabzevari H: Inhibition of CD4(+)25+ T regulatory cel function implicated in enhanced immune response by low-dose cyclophosphamide. Blood 105: 2862-2868, 2005

40. Heylmann D, Bauer M, Becker H, van Gool S, Bacher N, Steinbrink K and Kaina B: Human CD4+CD25+ regulatory $\mathrm{T}$ cells are sensitive to low dose cyclophosphamide: Implications for the immune response. PLoS One 8: e83384, 2013.

41. Traverso I, Fenoglio D, Negrini S, Parodi A, Battaglia F, Kalli F, Conteduca G, Tardito S, Traverso P, Indiveri F and Filaci G Cyclophosphamide inhibits the generation and function of CD8(+) regulatory T cells. Hum Immunol 73: 207-213, 2012.

42. Ghiringhelli F, Larmonier N, Schmitt E, Parcellier A, Cathelin D, Garrido C, Chauffert B, Solary E, Bonnotte B and Martin F: CD4+CD25+ regulatory $T$ cells suppress tumor immunity but are sensitive to cyclophosphamide which allows immunotherapy of established tumors to be curative. Eur J Immunol 34: 336-344, 2004.

43. Kwa M, Li X, Novik Y, Oratz R, Jhaveri K, Wu J, Gu P, Meyers M, Muggia F, Speyer J, et al: Serial immunological parameters in a phase II trial of exemestane and low-dose oral cyclophosphamide in advanced hormone receptor-positive breast cancer. Breast Cancer Res Treat 168: 57-67, 2018.

44. Mumtaz IM, Hoyer BF, Panne D, Moser K, Winter O, Cheng QY, Yoshida T, Burmester GR, Radbruch A, Manz RA and Hiepe F: Bone marrow of NZB/W mice is the major site for plasma cells resistant to dexamethasone and cyclophosphamide: Implications for the treatment of autoimmunity. J Autoimmun 39: 180-188, 2012.

45. Brodsky RA: High-dose cyclophosphamide for autoimmunity and alloimmunity. Immunol Res 47: 179-184, 2010.

46. Lamers CH, Willemsen $R$, van Elzakker $P$, van Steenbergen-Langeveld S, Broertjes M, Oosterwijk-Wakka J, Oosterwijk E, Sleijfer S, Debets R and Gratama JW: Immune responses to transgene and retroviral vector in patients treated with ex vivo-engineered T cells. Blood 117: 72-82, 2011.

47. Muranski P, Boni A, Wrzesinski C, Citrin DE, Rosenberg SA, Childs R and Restifo NP: Increased intensity lymphodepletion and adoptive immunotherapy-how far can we go? Nat Clin Pract Oncol 3: 668-681, 2006.

48. Rosenberg SA and Dudley ME: Adoptive cell therapy for the treatment of patients with metastatic melanoma. Curr Opin Immunol 21: 233-240, 2009.

49. Qiao J, Liu Z and Fu YX: Adapting conventional cancer treatment for immunotherapy. J Mol Med (Berl) 94: 489-495, 2016.

50. Wang W, Kryczek I, Dostál L, Lin H, Tan L, Zhao L, Lu F, Wei S, Maj T, Peng D, et al: Effector T cells abrogate stroma-mediated chemoresistance in ovarian cancer. Cell 165: 1092-1105, 2016.

51. Reits EA, Hodge JW, Herberts CA, Groothuis TA, Chakraborty M, Wansley EK, Camphausen K, Luiten RM, de Ru AH, Neijssen J, et al: Radiation modulates the peptide repertoire, enhances MHC class I expression, and induces successful antitumor immunotherapy. J Exp Med 203: 1259-1271, 2006.

52. Gaipl US, Multhoff G, Scheithauer H, Lauber K, Hehlgans S, Frey B and Rödel F: Kill and spread the word: Stimulation of antitumor immune responses in the context of radiotherapy. Immunotherapy 6: 597-610, 2014.
53. Higgins JP, Bernstein MB and Hodge JW: Enhancing immune responses to tumor-associated antigens. Cancer Biol Ther 8: $1440-1449,2009$

54. Sharma A, Bode B, Wenger RH, Lehmann K, Sartori AA, Moch H, Knuth A, Boehmer Lv and Broek Mv: $\gamma$-Radiation promotes immunological recognition of cancer cells through increased expression of cancer-testis antigens in vitro and in vivo. PLoS One 6: e28217, 2011.

55. Lee Y, Auh SL, Wang Y, Burnette B, Wang Y, Meng Y, Beckett M, Sharma R, Chin R, Tu T, et al: Therapeutic effects of ablative radiation on local tumor require $\mathrm{CD} 8+\mathrm{T}$ cells: Changing strategies for cancer treatment. Blood 114: 589-595, 2009.

56. Lugade AA, Sorensen EW, Gerber SA, Moran JP, Frelinger JG and Lord EM: Radiation-induced IFN-gamma production within the tumor microenvironment influences antitumor immunity. J Immunol 180: 3132-3139, 2008

57. Ganss R, Ryschich E, Klar E, Arnold B and Hämmerling GJ: Combination of T-cell therapy and trigger of inflammation induces remodeling of the vasculature and tumor eradication. Cancer Res 62: 1462-1470, 2002.

58. Aymeric L, Apetoh L, Ghiringhelli F, Tesniere A, Martins I, Kroemer G, Smyth MJ and Zitvogel L: Tumor cell death and ATP release prime dendritic cells and efficient anticancer immunity. Cancer Res 70: 855-858, 2010.

59. Zhang B, Bowerman NA, Salama JK, Schmidt H, Spiotto MT, Schietinger A, Yu P, Fu YX, Weichselbaum RR, Rowley DA, et al: Induced sensitization of tumor stroma leads to eradication of established cancer by T cells. J Exp Med 204: 49-55, 2007.

60. Matsumura S, Wang B, Kawashima N, Braunstein S, Badura M, Cameron TO, Babb JS, Schneider RJ, Formenti SC, Dustin ML and Demaria S: Radiation-induced CXCL16 release by breast cancer cells attracts effector T cells. J Immunol 181: 3099-3107, 2008.

61. Liao YP, Wang CC, Butterfield LH, Economou JS, Ribas A, Meng WS, Iwamoto KS and McBride WH: Ionizing radiation affects human MART-1 melanoma antigen processing and presentation by dendritic cells. J Immunol 173: 2462-2469, 2004.

62. Crouse J, Kalinke U and Oxenius A: Regulation of antiviral $\mathrm{T}$ cell responses by type I interferons. Nat Rev Immunol 15: 231-242, 2015.

63. Burnette BC, Liang H, Lee Y, Chlewicki L, Khodarev NN, Weichselbaum RR, Fu YX and Auh SL: The efficacy of radiotherapy relies upon induction of type $\mathrm{i}$ interferon-dependent innate and adaptive immunity. Cancer Res 71: 2488-2496, 2011.

64. Deng L, Liang H, Xu M, Yang X, Burnette B, Arina A, Li XD, Mauceri H, Beckett M, Darga T, et al: STING-Dependent Cytosolic DNA sensing promotes radiation-induced type I interferon-dependent antitumor immunity in immunogenic tumors. Immunity 41: 843-852, 2014.

65. Diamond MS, Kinder M, Matsushita H, Mashayekhi M, Dunn GP, Archambault JM, Lee H, Arthur CD, White JM, Kalinke U, et al: Type I interferon is selectively required by dendritic cells for immune rejection of tumors. J Exp Med 208: 1989-2003, 2011.

66. Fuertes MB, Kacha AK, Kline J, Woo SR, Kranz DM, Murphy KM and Gajewski TF: Host type I IFN signals are required for antitumor CD8+ T cell responses through CD8\{alpha $\}+$ dendritic cells. J Exp Med 208: 2005-2016, 2011.

67. Kang J, Demaria S and Formenti S: Current clinical trials testing the combination of immunotherapy with radiotherapy. J Immunother Cancer 4: 51, 2016.

68. Rodriguez-Ruiz ME, Rodriguez I, Garasa S, Barbes B, Solorzano JL, Perez-Gracia JL, Labiano S, Sanmamed MF, Azpilikueta A, Bolaños E, et al: Abscopal effects of radiotherapy are enhanced by combined immunostimulatory mAbs and Are dependent on CD8 T cells and crosspriming. Cancer Res 76: 5994-6005, 2016

69. Demaria S, Ng B, Devitt ML, Babb JS, Kawashima N, Liebes L and Formenti SC: Ionizing radiation inhibition of distant untreated tumors (abscopal effect) is immune mediated. Int J Radiat Oncol Biol Phys 58: 862-870, 2004.

70. Weiss T, Weller M, Guckenberger M, Sentman CL and Roth P NKG2D-based CAR T cells and radiotherapy exert synergistic efficacy in glioblastoma. Cancer Res 78: 1031-1043, 2018.

71. Yovino S and Grossman SA: Severity, etiology and possible consequences of treatment-related lymphopenia in patients with newly diagnosed high-grade gliomas. CNS Oncol 1: 149-154, 2012

72. Baniyash M: TCR zeta-chain downregulation: Curtailing an excessive inflammatory immune response. Nat Rev Immunol 4: 675-687, 2004.

73. Alanio C, Lemaitre F, Law HK, Hasan M and Albert ML: Enumeration of human antigen-specific naive CD8+ T cells reveals conserved precursor frequencies. Blood 115: 3718-3725, 2010. 
74. Yoo EJ, Park JC, Kim EH, Park CH, Shim CN, Lee HJ, Chung HS, Lee H, Shin SK, Lee SK, et al: Prognostic value of neutrophil-to-lymphocyte ratio in patients treated with concurrent chemoradiotherapy for locally advanced oesophageal cancer. Dig Liver Dis 46: 846-853, 2014.

75. Gazdic M, Simovic Markovic B, Jovicic N, Misirkic-Marjanovic M, Djonov V, Jakovljevic V, Arsenijevic N Lukic ML and Volarevic V: Mesenchymal stem cells promote metastasis of lung cancer cells by downregulating systemic antitumor immune response. Stem Cells Int 2017: 6294717, 2017

76. Nelson A, Nair S and Nagaraj S: CD4(+) T cells suppress immune response to cancer: Novel targets for antitumor efforts. Expert Rev Clin Immunol 8: 401-403, 2012.

77. Zhang Q, Yang XJ, Kundu SD, Pins M, Javonovic B, Meyer R, Kim SJ, Greenberg NM, Kuzel T, Meagher R, et al: Blockade of transforming growth factor-\{beta\} signaling in tumor-reactive CD8(+) T cells activates the antitumor immune response cycle. Mol Cancer Ther 5: 1733-1743, 2006.

78. Galon J, Costes A, Sanchez-Cabo F, Kirilovsky A, Mlecnik B, Lagorce-Pagès $\mathrm{C}$, Tosolini M, Camus $\mathrm{M}$, Berger $\mathrm{A}$, Wind $\mathrm{P}$, et al: Type, density, and location of immune cells within human colorectal tumors predict clinical outcome. Science 313: 1960-1964, 2006.

79. Tang C, Liao Z, Gomez D, Levy L, Zhuang Y, Gebremichael RA, Hong DS, Komaki R and Welsh JW: Lymphopenia association with gross tumor volume and lung V5 and its effects on non-small cell lung cancer patient outcomes. Int J Radiat Oncol Biol Phys 89: 1084-1091, 2014.

80. Kitayama J, Yasuda K, Kawai K, Sunami E and Nagawa H: Circulating lymphocyte number has a positive association with tumor response in neoadjuvant chemoradiotherapy for advanced rectal cancer. Radiat Oncol 5: 47, 2010.

81. Schueneman AJ, Sugar EA, Uram J, Bigelow E, Herman JM, Edil BH, Jaffee EM, Zheng L and Laheru DA: Low total lymphocyte count is associated with poor survival in patients with resected pancreatic adenocarcinoma receiving a GM-CSF secreting pancreatic tumor vaccine. Ann Surg Oncol 20 (Suppl 3): S725-S730, 2013

82. Buka D, Dvořák J, Sitorová V, Hátlová J, Richter I and Sirák I: Changes in the CD8+ density of tumor infiltrating lymphocytes after neoadjuvant radiochemotherapy in patients with rectal adenocarcinom. Klin Onkol 29: 204-209, 2016.

83. Zitvogel L, Kepp O and Kroemer G: Immune parameters affecting the efficacy of chemotherapeutic regimens. Nat Rev Clin Oncol 8: 151-160, 2011

84. Aranda F, Buqué A, Bloy N, Castoldi F, Eggermont A, Cremer I, Fridman WH, Fucikova J, Galon J, Spisek R, et al: Trial watch: Adoptive cell transfer for oncological indications. Oncoimmunology 4: e1046673, 2015.

85. Domschke C, Schneeweiss A, Stefanovic S, Wallwiener M, Heil J, Rom J,Sohn C,Beckhove P and SchuetzF: Cellularimmune responses and immune escape mechanisms in breast cancer: Determinants of immunotherapy. Breast Care (Basel) 11: 102-107, 2016.

86. Ruella $\mathrm{M}$ and Kalos M: Adoptive immunotherapy for cancer. Immunol Rev 257: 14-38, 2014.

87. Henick BS, Herbst RS and Goldberg SB: The PD-1 pathway as a therapeutic target to overcome immune escape mechanisms in cancer. Expert Opin Ther Targets 18: 1407-1420, 2014.

88. Steinert G, Schölch S, Niemietz T, Iwata N, García SA, Behrens B, Voigt A, Kloor M, Benner A, Bork U, et al: Immune escape and survival mechanisms in circulating tumor cells of colorectal cancer. Cancer Res 74: 1694-1704, 2014.

89. Radziewicz H, Ibegbu CC, Fernandez ML, Workowski KA, Obideen K, Wehbi M, Hanson HL, Steinberg JP, Masopust D, Wherry EJ, et al: Liver-infiltrating lymphocytes in chronic human hepatitis $\mathrm{C}$ virus infection display an exhausted phenotype with high levels of PD-1 and low levels of CD127 expression. J Virol 81: 2545-2553, 2007.

90. Chauvin JM, Pagliano O, Fourcade J, Sun Z, Wang H, Sander C, Kirk wood JM, Chen TH, Maurer M, Korman AJ and Zarour HM TIGIT and PD-1 impair tumor antigen-specific CD8+ T cells in melanoma patients. J Clin Invest 125: 2046-2058, 2015.

91. Neagu MR and Reardon DA: An update on the role of immunotherapy and vaccine strategies for primary brain tumors. Curr Treat Options Oncol 16: 54, 2015

92.John LB, Devaud C, Duong CP, Yong CS, Beavis PA, Haynes NM, Chow MT, Smyth MJ, Kershaw MH and Darcy PK Anti-PD-1 antibody therapy potently enhances the eradication of established tumors by gene-modified $\mathrm{T}$ cells. Clin Cancer Res 19: 5636-5646, 2013.
93. Liu X, Ranganathan R, Jiang S, Fang C, Sun J, Kim S, Newick K, Lo A, June CH, Zhao Y and Moon EK: A chimeric switch-receptor targeting PD1 augments the efficacy of second-generation CAR T cells in advanced solid tumors. Cancer Res 76: 1578-1590, 2016.

94. Cogdill AP, Andrews MC and Wargo JA: Hallmarks of response to immune checkpoint blockade. Br J Cancer 117: 1-7, 2017.

95. Moon EK, Wang LC, Dolfi DV, Wilson CB, Ranganathan R, Sun J, Kapoor V, Scholler J, Puré E, Milone MC, et al: Multifactorial T-cell hypofunction that is reversible can limit the efficacy of chimeric antigen receptor-transduced human T cells in solid tumors. Clin Cancer Res 20: 4262-4273, 2014.

96. Burga RA, Thorn M, Point GR, Guha P, Nguyen CT, Licata LA, DeMatteo RP, Ayala A, Joseph Espat N, Junghans RP and Katz SC: Liver myeloid-derived suppressor cells expand in response to liver metastases in mice and inhibit the anti-tumor efficacy of anti-CEA CAR-T. Cancer Immunol Immunother 64: 817-829, 2015.

97. Suarez ER, Chang de K, Sun J, Sui J, Freeman GJ, Signoretti S, Zhu Q and Marasco WA: Chimeric antigen receptor T cells secreting anti-PD-L1 antibodies more effectively regress renal cell carcinoma in a humanized mouse model. Oncotarget 7: 34341-34355, 2016.

98. Rosewell Shaw A, Porter CE, Watanabe N, Tanoue K, Sikora A, Gottschalk S, Brenner MK and Suzuki M: Adenovirotherapy delivering cytokine and checkpoint inhibitor augments CAR T cells against metastatic head and neck cancer. Mol Ther 25: 2440-2451, 2017.

99. Li S, Siriwon N, Zhang X, Yang S, Jin T, He F, Kim YJ, Mac J, Lu Z, Wang S, et al: Enhanced cancer immunotherapy by chimeric antigen receptor-modified $\mathrm{T}$ cells engineered to secrete checkpoint inhibitors. Clin Cancer Res 23: 6982-6992, 2017.

100. Serganova I, Moroz E, Cohen I, Moroz M, Mane M, Zurita J, Shenker L, Ponomarev V and Blasberg R: Enhancement of PSMA-directed CAR adoptive immunotherapy by PD-1/PD-L1 blockade. Mol Ther Oncolytics 4: 41-54, 2016.

101. Gargett T, Yu W, Dotti G, Yvon ES, Christo SN, Hayball JD, Lewis ID, Brenner MK and Brown MP: GD2-specific CAR T cells undergo potent activation and deletion following antigen encounter but can be protected from activation-induced cell death by PD-1 blockade. Mol Ther 24: 1135-1149, 2016.

102. Scarfò I and Maus MV: Current approaches to increase CAR T cell potency in solid tumors: Targeting the tumor microenvironment. J Immunother Cancer 5: 28, 2017.

103. Di Stasi A,De Angelis B, Rooney CM,Zhang L, Mahendravada A, Foster AE, Heslop HE, Brenner MK, Dotti G and Savoldo B: $\mathrm{T}$ lymphocytes coexpressing CCR4 and a chimeric antigen receptor targeting CD30 have improved homing and antitumor activity in a Hodgkin tumor model. Blood 113: 6392-6402, 2009.

104. Kershaw MH, Wang G, Westwood JA, Pachynski RK, Tiffany HL, Marincola FM, Wang E, Young HA, Murphy PM and Hwu P: Redirecting migration of $T$ cells to chemokine secreted from tumors by genetic modification with CXCR2. Hum Gene Ther 13: 1971-1980, 2002.

105. Xia T, Konno H and Barber GN: Recurrent loss of STING signaling in melanoma correlates with susceptibility to viral oncolysis. Cancer Res 76: 6747-6759, 2016.

106. Ajina A and Maher J: Prospects for combined use of oncolytic viruses and CAR T-cells. J Immunother Cancer 5: 90, 2017.

107. Kim DS, Dastidar H, Zhang C, Zemp FJ, Lau K, Ernst M, Rakic A Sikdar S, Rajwani J, Naumenko V, et al: Smac mimetics and oncolytic viruses synergize in driving anticancer T-cell responses through complementary mechanisms. Nat Commun 8: 344, 2017.

108. Scott EM, Duffy MR, Freedman JD, Fisher KD and Seymour LW: Solid tumor immunotherapy with T cell engager-armed oncolytic viruses. Macromol Biosci 18: Jan, 2018. doi: 10.1002/mabi.201700187

109. Nishio N and Dotti G: Oncolytic virus expressing RANTES and IL-15 enhances function of CAR-modified T cells in solid tumors. Oncoimmunology 4: e988098, 2015.

110. Nishio N, Diaconu I, Liu H, Cerullo V, Caruana I, Hoyos V, Bouchier-Hayes L, Savoldo B and Dotti G: Armed oncolytic virus enhances immune functions of chimeric antigen receptor-modified T cells in solid tumors. Cancer Res 74: 5195-5205, 2014

111. Gilham DE, Debets R, Pule M, Hawkins RE and Abken H: CAR-T cells and solid tumors: Tuning $T$ cells to challenge an inveterate foe. Trends Mol Med 18: 377-384, 2012.

112. Sathyanarayanan V and Neelapu SS: Cancer immunotherapy: Strategies for personalization and combinatorial approaches. Mol Oncol 9: 2043-2053, 2015.

This work is licensed under a Creative Commons Attribution-NonCommercial-NoDerivatives 4.0 International (CC BY-NC-ND 4.0) License. 